\title{
KARAKTERISTIK MIKROKAPSUL ANTOSIANIN UBI JALAR UNGU DENGAN TEKNIK SPRAY DRYING
}

\section{CHARACTERISTICS OF PURPLE SWEET POTATO'S ANTHOCYANIN MICROCAPSULES WITH SPRAY DRYING TECHNIQUE}

\author{
Anting Wulandari, Titi Candra Sunarti, Farah Fahma, Erliza Noor \\ Program Studi Teknologi Industri Pertanian, Sekolah Pascasarjana Institut Pertanian Bogor \\ Kampus IPB Darmaga, PO Box 220 Bogor 16002, Indonesia \\ Email: antingwulandari3@gmail.com \\ Makalah: Diterima 28 Agustus 2018; Diperbaiki 12 Maret 2019; Disetujui 25 Maret 2019
}

\begin{abstract}
Anthocyanin is a source of natural dyes that can replace synthetic dyes. Its nature which is susceptible to certain environmental conditions limits its usefulness in food processing, so it is necessary to encapsulate it in a matrix in the form of microencapsulation. Anthocyanin was extracted from purple sweet potato. Encapsulation was carried out by spray drying technique with the matrix carboxymethyl starch (CMS) and sodium alginate. The matrix combinations used were 1\% CMS, CMS-alginate (0.75\%: 0.25\%), and CMS-alginate (0.5\%: $0.5 \%)$. The aim of this work was to obtain the physical and morphological characteristics of purple sweet potato anthocyanin microcapsules in each matrix combination. The results of the purple sweet potato anthocyanin micro encapsulation using spray dyring technique showed that microcapsules with CMS matrix of $1 \%$ had the highest efficiency encapsulation (EE) and yield of $99.37 \pm 0.49 \%$ and $58.52 \pm 0.23 \%$ respectively. Purple sweet potato anthocyanin microcapsules with CMS $1 \%$ matrix gave the best thermal stability compared to CMSalginate matrix (0.5\%:0.5\%) and CMS-alginate (0.75\%:0.25\%). The average particle size for purple sweet potato anthocyanin microcapsules from various matrices ranged from 4.2-4.8 $\mu \mathrm{m}$ with a rounded shape.
\end{abstract}

Keywords: anthocyanin, microcapsule, CMS, alginate, spray drying

\section{ABSTRAK}

Antosianin merupakan sumber pewarna alami yang dapat menggantikan pewarna sintetis. Sifatnya yang rentan oleh kondisi lingkungan tertentu membatasi kegunaannya dalam proses pengolahan pangan, sehingga perlu mengenkapsulasinya dalam suatu matriks dalam bentuk mikroenkapsulasi. Antosianin diekstrak dari ubi jalar ungu. Enkapsulasi dilakukan dengan teknik spray drying dengan matriks carboxymethyl starch (CMS) dan natrium alginat. Adapun kombinasi matriks yang digunakan yaitu CMS 1\%, CMS-alginat (0,75\%:0,25\%), dan CMS-alginat (0,5\%:0,5\%). Tujuan dari penelitian ini adalah memperoleh karakteristik fisik dan morfologi mikrokapsul antosianin pada masing-masing kombinasi matriks. Hasil mikroenkapsulasi antosianin ubi jalar ungu dengan teknik spray dyring menunjukkan bahwa mikrokapsul dengan matriks CMS $1 \%$ memiliki efisiensi enkapsulasi dan rendemen tertinggi masing-masing sebesar 99,37 $\pm 0,49 \%$ dan 58,52 $\pm 0,23 \%$. Mikrokapsul antosianin ubi jalar ungu dengan matriks CMS $1 \%$ memberikan kestabilan termal terbaik dibanding matriks CMS-alginat $(0,75 \%: 0,25 \%)$ dan CMS-alginat (0,5\%:0,5\%). Ukuran partikel rata-rata untuk mikrokapsul antosianin ubi jalar ungu dari berbagai matriks berkisar 4,2-4,8 $\mu \mathrm{m}$ dengan bentuk cenderung bulat berpermukaan halus.

Kata kunci : antosianin, CMS, alginat, spray drying, mikrokapsul

\section{PENDAHULUAN}

Bahan aktif alami merupakan sumber bahan alam yang melimpah di Indonesia. Antosianin merupakan komponen bioaktif kelompok flavonoid yang memiliki warna bervariasi meliputi merah, biru, dan ungu pada bunga, daun, umbi, buah dan sayur dengan intensitas warna tergantung pada $\mathrm{pH}$ nya (Torskangerpoll dan Andersen, 2005; Burdulis et al.,2009; Jensen et al.,2011).

Antosianin mudah larut dalam air dan aman dikonsumsi sehingga sering digunakan sebagai pewarna alami pada makanan dan minuman (Chisté et al.,2010). Beberapa ekstrak kaya antosianin dari buah-buahan dan sayuran dapat digunakan sebagai pewarna makanan untuk menggantikan pewarna sintetis untuk keamanan konsumen. Meskipun pewarna sintetis pangan lebih murah, stabil dan memberikan warna yang menarik dibanding pewarna alami, namun menurut Budimarwanti (1992) penggunaannya yang melebihi ambang batas yang diizikan (diatur dalam Peraturan Menteri Kesehatan RI. No 722/Menkes/Per/IX/1988 tentang bahan tambahan makanan) dapat menimbulkan efek tertentu seperti rasa makanan menjadi pahit dan keracunan. Oleh karenanya, pewarna alami lebih aman dikonsumsi dibanding pewarna sintetis.

Selain sebagai sumber pewarna alami, antosianin juga menunjukkan sejumlah fungsi 
biologis diantaranya memiliki aktivitas antioksidan dan anti-karsinogen, dan kemampuan untuk meningkatkan memori (Cho et al., 2003; Hwang et al., 2011). Ubi jalar ungu (Ipomoea batatas L) varietas Ayamurasaki menjadi salah satu sumber bahan alam yang menghasilkan antosianin. Menurut Montilla et al. (2010) antosianin yang dominan di dalam ubi jalar ungu adalah 3-sophorosida-5glukosida turunan peonidin dan sianidin.

Antosianin rentan terhadap panas, cahaya, $\mathrm{pH}$, oksigen dan beberapa enzim seperti polifenol oksidase, yang membatasi kegunaannya dalam pengolahan makanan (Cavalcanti et al., 2011; Malien-Aubert et al., 2001). Dengan demikian untuk meningkatkan kestabilan antosianin, diperlukan media penstabil, yaitu dengan mengikat bahan aktiftersebut dengan matriks pembawa (carrier matrix) dalam bentuk mikroenkapsulasi. Menurut Gharsallaoui et al. (2007) mikroenkapsulasi merupakan sebuah teknik dimana bioaktif dienkapsulasi dalam biopolimer untuk melindunginya dari oksigen, cahaya, air atau kondisi lain dan juga mengubah larutan menjadi dalam bentuk bubuk supaya mempermudah penangananya.

Mikroenkapsulasi dapat dilakukan dengan spray drying. Spray drying adalah teknik yang umum digunakan untuk enkapsulasi antosianin dan 80-90\% enkapsulat dikeringkan secara semprot. Menurut Mahdavi et al. (2014) metode ini sering digunakan dalam industri makanan karena biaya operasinya rendah, operasi dapat berjalan terusmenerus, kualitas kapsul yang dihasilkan tinggi dalam rendemen yang baik, ukuran kapsul kecil, kelarutan kapsul tinggi, dan kapsul yang dihasilkan memiliki stabilitas yang baik. Parameter penting dalam teknik spray drying adalah suhu inlet, laju alir umpan, dan suhu outlet. Menurut Rennecius et al.(1988) semakin tinggi suhu udara yang digunakan untuk pengeringan, maka proses penguapan air pada bahan akan semakin cepat, akan tetapi suhu yang tinggi memungkinkan terjadinya kerusakan secara fisik maupun kimia pada bahan yang tidak tahan panas. Rentang suhu inlet yang umumnya aman digunakan dan menghasilkan retensi yang baik adalah $120-200^{\circ} \mathrm{C}$ (Tonon et al., 2008), dengan laju alir umpan 5-10 mL/menit (Shaikh et al.,2006; Olaya et al., 2009), dan suhu outlet $80-112^{\circ} \mathrm{C}$ (Nayak dan Rastogi, 2010; Tonon et al., 2008).

Beberapa matriks/wall yang dapat digunakan sebagai agen enkapsulasi antosianin diantaranya maltodekstrin, protein isolat kedelai (Robert et al., 2010), alginat (de Oliveira et al., 2014), pati termodifikasi (Porrarud dan Pranee, 2010; Spada et al., 2012) dan pati jagung (Arueya dan Akomolafe, 2014). Dalam penelitian ini matriks enkapsulasi yang digunakan adalah pati termodifikasi Carboxymethyl starch (CMS) dan alginat. Diantara beberapa produk turunan pati, CMS merupakan produk turunan pati yang sangat penting.
Carboxymethyl starch merupakan pati termodifikasi yang terbentuk melalui proses karboksimetilasi yaitu dengan mensubstitusi gugus hidroksil $(-\mathrm{OH})$ dalam molekul pati dengan gugus karboksimetil $\left(\mathrm{CH}_{2} \mathrm{COOH}\right)$. Carboxymethyl starch memiliki tingkat kejernihan film yang baik, kekentalan, dan kelarutan dalam air yang lebih baik dibanding pati aslinya dan dapat larut dalam air dingin (Sangseethong et al., 2005; Spychaj et al., 2013).

Matriks lain, alginat merupakan metabolit primer senyawa hidrokoloid penting sehingga banyak dimanfaatkan oleh industri pangan sebagai pengental, pembentuk gel, stabilizer, dan bahan pengemulsi. Alginat memiliki sifat unik dan luar biasa yang menjelaskan kemampuannya membentuk, bola, mikro dan nanopartikel (Wu et al., 2012; Li et al., 2012). Selain itu, alginat telah terbukti bersifat biodegradable biocompatible, dan non-toksik (Espevik et al., 1993). Penelitian ini bertujuan untuk untuk memperoleh karakteristik fisik dan morfologi mikrokapsul antosianin ubi jalar ungu dengan menggunakan matriks kombinasi CMS dan alginat pada berbagai konsentrasi.

\section{Bahan}

\section{BAHAN DAN METODE}

Bahan yang digunakan diantaranya ubi jalar ungu varietas Ayamurasaki yang dibeli dari pasar tani, Cikarawang, Bogor, akuades, etanol 96\% (teknis grade), asam asetat glasial (Merck), natrium alginat (HiMedia), Carboxymethyl starch (DS 0,8) diperoleh dari hasil penelitian mahasiswa S-1 Teknologi Industri Pertanian IPB, natrium asetat (Merck), asam klorida (Merck), potasium klorida (Merck), dan natrium hidroksida (Merck). Peralatan yang digunakan berupa blender (Philips), vacuum filter (Value, 2 Stage Vacuum Pump, VE 2100 N), sentrifius (IEC Clinical Centrifuge, USA), kertas saring, homogenizer Ultra Turax (Armfield L4R) spray dryer (Buchi 190) dan peralatan gelas untuk analisa.

\section{Metode Penelitian}

Preparasi Sampel dan Ekstraksi Antosianin Ubi Jalar Ungu

Preparasi dan ekstraksi antosianin ubi jalar ungu mengadopsi metode dari kombinasi Mahmudatssa'adah (2014) dan Winarti et al. (2008) yang disajikan pada Gambar 1.

\section{Analisis Total Antosianin Metode Spektrofotometer \\ Pengukuran total antosianin ekstrak ubi jalar ungu dilakukan menggunakan Spektrofotometer UV VIS Merk Genesys pada rentang panjang gelombang 500-700 nm. Disiapkan 2 sampel larutan, larutan pertama adalah larutan untuk pH 1,0 menggunakan buffer $\mathrm{KCl}(0,2 \mathrm{M})$ dan larutan kedua untuk $\mathrm{pH}$ 4,5 menggunakan buffer Na- Asetat (0,1 M).}




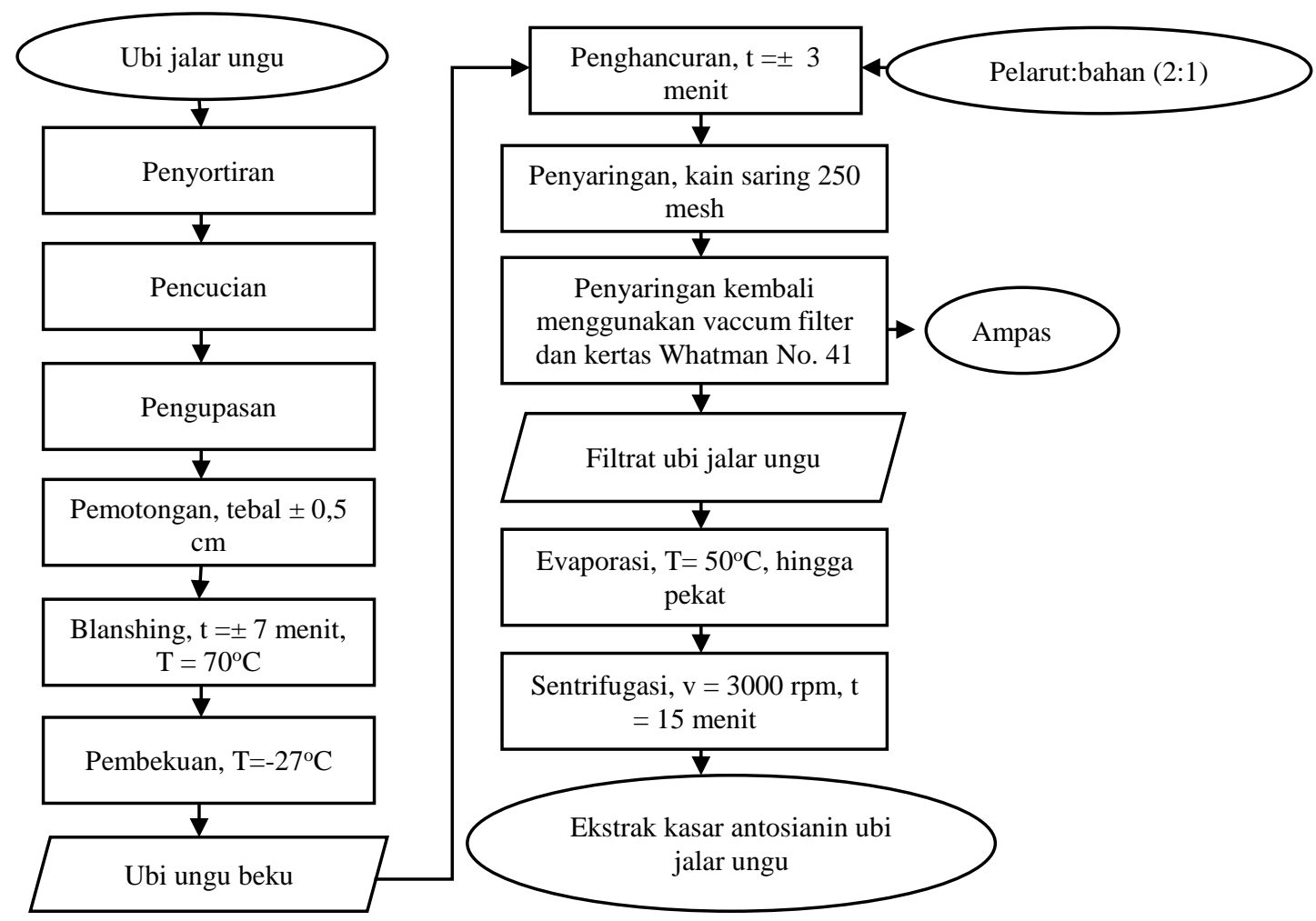

Gambar 1. Diagram alir ekstraksi antosianin ubi jalar ungu

Selanjutnya masing-masing ekstrak antosianin ubi jalar ungu diambil sebanyak $1 \mathrm{~mL}$ kemudian diencerkan menggunakan larutan buffer masing-masing sampai volume $10 \mathrm{~mL}$ (Faktor pengenceran $=10)$. Sampel hasil pengenceran masing-masing dilakukan pengukuran absorbansi pada $\boldsymbol{\lambda}$ maks (510) dan $\boldsymbol{\lambda} 700 \mathrm{~nm}$ (Cheng dan Breen, 1991). Metode pengukuran diadopsi dari Giusti dan Wrolstad (2001) dengan menggunakan persamaan 1.

$A=\left(\begin{array}{lll}A \lambda \text { vis } \max & -A & 700\end{array}\right) \mathrm{pH} 1,0-\left(\begin{array}{l}A \lambda \text { vis } \max -A 700\end{array}\right)$ $\mathrm{pH} 4,5$

Dengan total konsentrasi antosianin dapat dihitung berdasarkan persamaan 2:

Total antosianin $\left(\frac{m g}{L}\right)=$ AxDf $x M W \times 1000$

Dengan:

$$
\begin{array}{llll}
\mathrm{Df} & = & \text { faktor dilusi } & \\
\mathrm{A} & = & \text { nilai absorbansi } & \\
\mathrm{Mw} & = & \text { berat molekul }(449,2) & \\
\varepsilon & = & \text { koefisien absorptivity molar } \\
& & (26900) &
\end{array}
$$

\section{Pengukuran Viskositas Gel Ekstrak Antosianin}

Viskositas gel antosianin hasil

homogenisasi ekstrak antosianin tersalut matriks diukur dengan menggunakan brookfield, kecepatan 30 rpm dengan spindel kecil.

\section{Enkapsulasi Antosianin Ubi Jalar Ungu}

Ekstrak kasar antosianin ubi jalar ungu dienkapsulasi dengan matriks kombinasi CMS dan alginat. Disiapkan suspensi matriks pati termodifikasi CMS yang dikombinasikan dengan kopolimer natrium alginat dengan formulasi CMS $1 \%$ (b/v), CMS-alginat (0,75\%:0,25\% (b/v)), CMSalginat $(0,5 \%: 0,5 \%(\mathrm{~b} / \mathrm{v}))$. Larutan gel matriks masing-masing dihomogenisasi dengan magnetic stirrer dengan kecepatan 500 (Hu et al., 2015) dalam waktu \pm 1 jam. Selanjutnya larutan gel matriks, masing-masing ditambahkan ekstrak kasar antosianin ubi jalar ungu dengan perbandingan 1:9 (ekstrak antosianin:suspensi matrik pati termodifikasi (v/v)) dengan total campuran keduanya adalah $500 \mathrm{~mL}$. Kemudian dilakukan homogenisasi dengan homogenizer Ultra-Turax berkecepatan $13000 \mathrm{rpm}$ selama 5 menit dan dilanjutkan dengan pengeringan menggunakan spray dryer mengadopsi penelitian Varavinit et al. (2001). Kondisi operasional pengeringan pada dryer adalah meodifikasi dari metode Nayak dan Rastogi (2010); Tonon et al. (2008), dan Shaikh et al.(2006), dengan kondisi sebagai berikut: suhu inlet diatur pada suhu $150^{\circ} \mathrm{C}$ dan suhu outlet diatur pada suhu $90 \pm 3{ }^{\circ} \mathrm{C}$, dengan laju alir umpan adalah $500 \mathrm{~mL} / \mathrm{jam}$. Masingmasing perlakukan dilakukan dua kali pengulangan, sehingga total kombinasi perlakuan adalah 6 kombinasi. 
Analisis Parameter Mutu Serbuk Mikrokapsul Antosianin Ubi Jalar Ungu

Pengukuran Efisiensi dan Rendemen

Efisiensi enkapsulasi dihitung sebagai rasio antara kadar antosianin permukaan dengan total antosianin enkapsulasi (Chin et al., 2014).

Efisiensi enkapsulasi $=$

[antosianin]total-[antosianin ]permukaan [antosianin]total

Adapaun prosedur pengukuran kadar antosianin permukaan mikrokapsul yaitu $0,1 \mathrm{~g}$ mikrokapsul antosianin dicuci dengan $45 \mathrm{~mL}$ etanol anhydrous selama 5 menit, lalu difilter dan ditambahkan ke dalam filtrat $1 \mathrm{~mL}$ aquades. Kadar antosianin dihitung dengan metode $\mathrm{pH}$ diferensial. Sementara tahapan pengukuran kadar antosianin total mikrokapsul adalah $0,1 \mathrm{~g}$ mikrokapsul antosianin ditambah $1 \mathrm{~mL}$ aquades dan digrounded untuk mendegradasi membran mikrokapsul. Kemudian ditambahkan $9 \mathrm{~mL}$ etanol anhydrous dan dibiarkan selama 5 menit lalu difiltrasi dan diukur kadar antosianinnya dengan metode $\mathrm{pH}$ diferensial (Zaidel et al., 2015).

Rendemen dihitung sebagai rasio antara bobot kering mikrokapsul antosianin ubi jalar ungu yang diperoleh dengan bobot awal campuran sebelum proses enkapsulasi. Rendemen mikrokapsul ditentukan dengan rumus berikut (Ahn et al.,2007):

Rendemen mikrokapsul $=$ $\frac{\text { bobot mikrokapsul (g) }}{\text { bobot padatan awal (g) }}$ X 100\%

\section{Analisis Kolorimetrik}

Warna serbuk mikroenkapsulasi diukur menggunakan colorimeter mengikuti sistem CIELAB ( $\left.\mathrm{L}^{*}, \mathrm{a}^{*}, \mathrm{~b}^{*}\right)$ dimana $\mathrm{L}^{*}$ mengindikasi kecerahan $(0=$ hitam, $100=$ hitam $), a^{*}$ dan $b^{*}$ adalah koordinat untuk hijau $\left(-\mathrm{a}^{*}\right) /$ merah $\left(+\mathrm{a}^{*}\right)$, biru ($\left.\mathrm{b}^{*}\right) /$ kuning $\left(+\mathrm{b}^{*}\right)$. Warna sampeldapat diketahui dari nilai derajat Hue, ${ }^{\circ}$ Hue $=\tan ^{-1} \mathrm{~b}^{*} / \mathrm{a}^{*}\left(0^{\circ}\right.$ atau $360^{\circ}=$ merah, $90^{\circ}=$ kuning, $180^{\circ}=$ hijau, dan $270^{\circ}=$ biru), sedangkan tingkat ketajaman warna yang dihasilkan dapat dilihat dari nilai chroma $(\mathrm{C}), \mathrm{C}=\left(\mathrm{a}^{* 2}+\mathrm{b}^{* 2}\right)^{1 / 2}$ (Kuck dan Noreña, 2016).

\section{Pengujian Stabilitas Termal Mikrokapsul}

Serbuk mikrokapsul antosianin ubi jalar ungu yang dihasilkan diuji stabilitas termal dengan cara serbuk mikropsul dipanaskan dengan oven pada suhu $100^{\circ} \mathrm{C}$ selama 2 jam. Metode ini diadopsi dari Winarti (2014). Kemudian diukur konsentrasi antosianin dalam mikrokapsul dan hasilnya diabandingkan dengan konsentrasi antosianin dalam mikrokapsul sebelum dipanaskan. Pengukuran konsentrasi antosianin dilakukan dengan melarutkan mikrokapsul menggunakan aquades, kemudian diencerkan dengan larutan buffer masing-masing dengan pH 1 dan pH 4,5 (Cheng dan Breen, 1991;
Giusti dan Wrolstad, 2001) seperti yang telah disebutkan sebelumnya pada sub bab "Analisis Total Antosianin Metode Spektrofotometer".

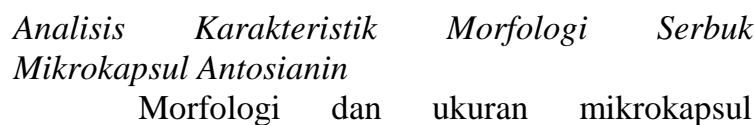
antosianin ubi jalar ungu dianalisa dengan menggunakan instrument Scanning Electron Microscope (SEM) di Laboratorium Balai Pascapanen, Cimanggu, Bogor. Serbuk mikrokapsul antosianin ubi jalar ungu sebanyak $\pm 3 \mathrm{~g}$ dimasukkan dalam plat platinum, kemudian permukaanya dicoating dengan emas. Plat platinum selanjutnya dimasukkan dalam alat SEM coating unit selama 15 menit. Diatur SEM dalam kondisi vakum dengan tegangan $20 \mathrm{kV}$. Kemudian permukaan mikrokapsul diamati dengan SEM yang telah terhubung dengan komputer dengan perbesaran yang diatur berdasarkan visualisasi terbaik (Winarti, 2014).

\section{$\underline{\text { Analisis Statistik }}$}

Masing-masing analisa dilakukan dua kali pengulangan. Analisa statistik dilakukan menggunakan software Microsoft Excel 2010, dan IBM SPSS versi 22. Beda nyata antara rat-rata perlakukan diuji lanjut dengan metode Duncan's multiple range test dengan tingkat kepercayaan $95 \%$ $(\alpha=0,05)$.

\section{HASIL DAN PEMBAHASAN}

\section{Viskositas Gel, Efisiensi Enkapsulasi dan} Rendemen Mikrokapsul Antosianin

Hasil analisis ragam menunjukkan bahwa jenis matriks berpengaruh sangat signifikan terhadap viskositas gel $(p=0,000)$, efisiensi enkapsulasi ( $p=$ $0,020)$, dan rendemen mikrokapsul antosianin $(p=0,000)$, karena masing-masing memiliki nilai $p<0,05$. Signifikansi pengaruh masing-masing varian matriks terhadap parameter dianalisis lebih lanjut dengan metode Duncan yang disajikan pada Tabel 1. Siginifikansi pengaruh varian matriks dilambangkan dengan notasi huruf pada setiap bilangan dari setiap kolom parameter. Notasi yang berbeda menunjukkan adanya pengaruh nyata antar varian matriks terhadap parameter yang diuji.

Berdasarkan Tabel 1, dengan tingkat kepercayaan 95\% $(\alpha=0,05)$, terlihat bahwa pengaruh matriks CMS $1 \%$ berbeda nyata dengan matriks CMS-alginat $(0,75 \%: 0,25 \%)$ dan matriks CMS-alginat $(0,5 \%: 0,5 \%)$ terhadap vikositas gel antosianin. Mikrokapsul dengan matriks CMS $1 \%$ memiliki viskositas gel paling kecil diantara kedua matriks lainnya yaitu sebesar 9,67 $\pm 0,55 \mathrm{Cps}$ dan viskositas tertinggi terjadi pada gel dengan matriks kombinasi CMS-alginat (0,75\%:0,25\%). Hasil korelasi varian matriks terhadap viskositas gel memberikan nilai regeresi linear $\left(\mathrm{R}^{2}\right)$ sebesar 0,97 , sehingga sebanyak $97 \%$, viskositas gel dipengaruhi 
oleh varian matriks dan $3 \%$ sisanya dipengaruhi oleh variabel lain. Dengan demikian penambahan natrium alginat pada CMS mampu meningkatkan viskositas gel antosianin yang dihasilkan.

Efisiensi enkapsulasi (EE) menunjukkan kemampuan bahan penyalut (matriks) dalam membungkus bahan aktif antosianin. Semakin tinggi nilai EE maka semakin baik matriks dalam menyalut/membungkus bahan aktif.. Berdasarkan Tabel 1 dapat dilihat bahwa mikrokapsul dengan matriks CMS $1 \%$ tanpa penambahan natrium alginat memiliki efisiensi enkapsulasi (EE) yaitu sebesar $99,37 \pm 0,49 \%$, sedangkan mikrokapsul dengan matriks kombinasi CMS-alginat $(0,75 \%: 0,25 \%)$ dan CMS-alginat $(0,5 \%: 0,5 \%)$ berturut-turut memiliki nilai EE sebesar 98,48 $\pm 0,51 \%$ dan 97,99 $\pm 0,22 \%$. Pada Tabel 1 juga dapat dilihat bahwa matriks CMS-alginat $(0,75 \%: 0,25 \%)$ dan CMSalginat $(0,5 \%: 0,5 \%)$ tidak memberikan pengaruh nyata terhadap nilai EE. Namun jika dibandingkan dengan kedua matriks, matriks CMS $1 \%$ memberikan pengaruh yang nyata terhadap nilai EE dengan nilai tertinggi yaitu sebesar 99,37 $\pm 0,49 \%$. Dengan demikian nilai efisiensi salah satunya dipengaruhi oleh jenis bahan penyalutnya. Menurut da Rosa et al. (2014) nilai EE sangat dipengaruhi oleh komponen terenkapsulasi dan bahan matriks yang digunakan.

Hasil penelitian Bryła (2015) menunjukkan nilai EE yang dihasilkan sebesar $69 \%$ untuk enkapsulasi ekstrak elderberry menggunakan matrik lesitin sunflower. Berdasarkan hal tersebut, pati termodifikasi CMS mampu mengikat dengan baik bahan aktif seperti antosianin, sehingga menghasilkan EE yang tinggi.

Selain dipengaruhi jenis bahan penyalut nilai efisiensi juga dipengaruhi oleh viskositas gel campuran bahan penyalut dan bahan tersalut (Robert dan Fredes, 2015). Viskositas gel yang dikeringkan dengan teknik pengeringan semprot berpengaruh terhadap partikel yang keluar melalui nozel. Viskositas yang rendah menyebabkan kurangnya energi dan tekanan dalam menghasilkan partikel pada atomisasi (Syafi'I, 2015). Hal serupa juga terjadi pada penelitian ini, viskositas gel antosianin memiliki hubungan yang linear terhadap efisiensi enkapsulasi yang dihasilkan. Hal tersebut dapat dilihat pada Gambar 2.

Gambar 2 menunjukkan bahwa semakin tinggi viskositas gel, maka efisiensi enkapsulasi semakin menurun dengan koefisien korelasi $\left(\mathrm{R}^{2}\right)$ sebesar 0,89. Signifikansi pengaruh masing-masing varian viskositas terhadap nilai EE ditunjukkan pada Tabel 1 dengan notasi huruf yang berbeda pada setiap bilangan dengan tren signifikansinya serupa dengan pengaruh jenis matriks terhadap nilai EE. Hal ini dikarenakan jenis matriks dan viskositas memiliki hubungan linear yang sangat baik $\left(\mathrm{R}^{2}=\right.$ 0,97). Pada viskositas 9,60 $\pm 0,55$, mikrokapsul memiliki nilai efisiensi enkapsulasi tertinggi diantara kedua matriks lainnya. Hal ini menunjukkan bahwa CMS dengan konsentrasi $1 \%$ tanpa dikombinasikan dengan natrium alginat memiliki viskositas yang optimal untuk dapat menghasilkan nilai efisiensi enkapsulasi terbaik.

Viskositas gel bahan tersalut dan matriks dapat pula mempengaruhi rendemen mikrokapsul yang dihasilkan. Gambar 3 menunjukkan bahwa seiring dengan meningkatnya viskositas gel campuran bahan tersalut dan bahan penyalut, rendemen mikrokapsul yang dihasilkan semakin turun pula, dengan koefisien korelasi $\left(\mathrm{R}^{2}\right)$ sebesar 0,91 . Hal ini menunjukkan signifikansi yang baik antara viskositas gel terhadap rendemen mikrokapsul. Signifikansi masing-masing varian viskositas gel serupa dengan tren jenis matriks terhadap mikrokapsul yang dilambangkan dengan notasi huruf berbeda. Viskositas yang dimiliki oleh masing-masing matriks memberikan pengaruh yang saling berbeda nyata terhadap rendemen mikrokapsul (Tabel 1).

Berdasarkan Tabel 1 dapat dilihat bahwa gel dengan matriks CMS $1 \%$ yang memiliki viskositas terendah mampu menghasilkan rendemen mikrokapsul tertinggi yaitu sebesar 58,52 $\pm 0,23 \%$. Hal ini terjadi karena dengan viskositas yang terlalu tinggi akan menyumbat keluarnya partikel dari nozel sehingga pengeringan menjadi terhambat, akibatnya rendemen mikrokapsul yang dihasilkan juga semakin kecil, seperti pada penelitian ini dengan viskositas yang semakin tinggi rendemen mikrokapsul memiliki kecenderungan menurun.

\section{Karakteristik Kolorimetrik Mikrokapsul}

Hasil penelitian karakteristik warna mikrokapsul antosianin ditunjukkan pada Tabel 2 . Berdasarkan Tabel 2 dapat dilihat bahwa mikrokapsul dengan matriks CMS $1 \%$ memiliki nilai $\mathrm{L}^{*}$ sebesar 56,31 \pm 0,79, dan mikrokapsul dengan matriks kombinasi CMS-alginat (0,75\%: $0,25 \%)$, dan (0,5\%: $0,5 \%)$ memiliki nilai $\mathrm{L}^{*}$ berturut-turut sebesar 56,90 $\pm 0,25$ dan57,42 $\pm 0,11$.

Tabel 1. Pengaruh jenis matriks terhadap viskositas gel, efisiensi enkapsulasi, dan rendemen enkapsulasi antosianin

\begin{tabular}{llll}
\hline \multicolumn{1}{c}{ Jenis matriks } & \multicolumn{1}{c}{ Viskositas gel (Cps) } & $\begin{array}{c}\text { Efisiensi Enkapsulasi } \\
(\text { EE) }(\%)\end{array}$ & $\begin{array}{c}\text { Rendemen } \\
\text { mikrokapsul (\%) }\end{array}$ \\
\hline CMS 1\% & $9,67 \pm 0,55^{\mathrm{a}}$ & $99,37 \pm 0,49^{\mathrm{a}}$ & $58,52 \pm 0,23^{\mathrm{a}}$ \\
CMS-alginat $(0,75 \%: 0,25 \%)$ & $16,33 \pm 0,84^{\mathrm{b}}$ & $98,48 \pm 0,51^{\mathrm{b}}$ & $49,43 \pm 0,13^{\mathrm{b}}$ \\
CMS-alginat $(0,5 \%: 0,5 \%)$ & $29,33 \pm 0,47^{\mathrm{c}}$ & $97,99 \pm 0,22^{\mathrm{b}}$ & $43,58 \pm 0,22^{\mathrm{c}}$ \\
\hline
\end{tabular}




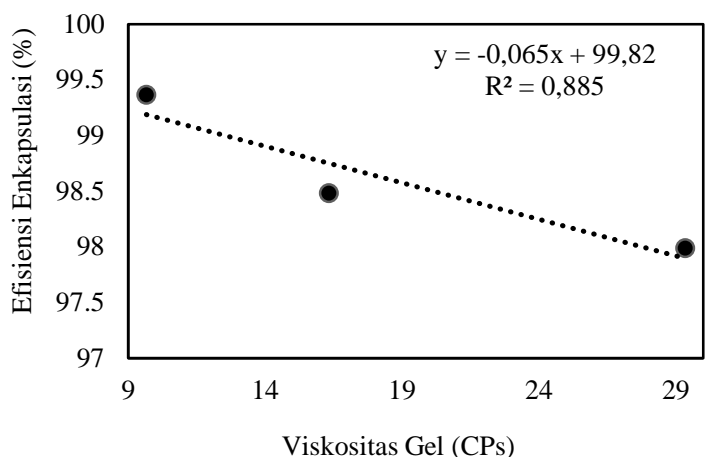

Gambar 2. Kurva linearitas viskositas gel antosianin terhadap efisiensi enkapsulasi

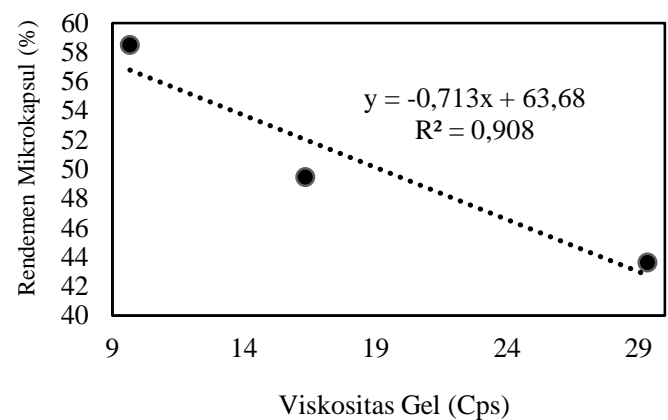

Gambar 3. Kurva linearitas viskositas gel antosianin terhadap rendemen mikrokapsul

Hasil analisis ragam dengan tingkat kepercayaan 95\% $(\alpha=0,05)$ menunjukkan bahwa jenis matriks tidak berpengaruh signifikan terhadap nilai $\mathrm{L}^{*}(p=0,219)$, $\mathrm{a}^{*}(p=0,272)$ dan $\mathrm{b}^{*}(0,788)$, dan chroma $(p=0,404)$, karena masing-masing memiliki nilai $p>0,05$ yang ditunjukkan pula oleh notasi huruf yang sama pada masing-masing nilai $\mathrm{L}^{*}$, $\mathrm{a}^{*}, \mathrm{~b}^{*}$ dan chroma (Tabel 2).

Nilai $\mathrm{L}^{*}$ mengindikasikan kecerahan $(0=$ hitam, $100=$ hitam), dan chroma menunjukkan saturasi atau kemurnian warna (Kuck dan Noreña 2016), sedangkan nilai a* (-) menunjukkan warna kehijauan, a* (+) menunjukkan warna kemerahan, nilai $b^{*}(-)$ menunjukkan warna kebiruan, dan $b^{*}(+)$ menunjukkan warna kekuningan (Lacerda et al., 2016). Berdasarkan hal tersebut menunjukkan bahwa mikrokapsul yang tersalut oleh masing-masing matriksmemiliki warna yang tidak jauh berbeda, dengan tingkat kecerahan dan ketajaman (saturasi) yang tidak jauh berbeda pula.
Nilai-nilai ${ }^{\circ}$ Hue antara 348 dan 359 menunjukkan kecenderungan sampel berwarna merah. Tabel 2 menunjukkan bahwa mikrokapsul antosianin untuk masing-masing matriks memiliki kecenderungan berwarna merah-kebiruan yang ditunjukkan dengan ${ }^{\circ}$ Hue di kuadran IV yaitu kisaran 329-330. Hasil ini sesuai dengan penelitian Kuck dan Noreña (2016).

Mikrokapsul dengan matriks CMS 1\% memiliki ${ }^{\circ}$ Hue 330,01 $\pm 0,08$ dan untuk mikrokapsul dengan matriks CMS-alginat $(0,75 \%: 0,25 \%)$ dan matriks CMS-alginat $(0,5 \%: 0,5 \%)$, berturut-turut memiliki nilai ${ }^{\circ}$ Hue sebesar 329,93 $\pm 0,14 ; 330,95 \pm$ 0,02 . Hasil analisa ragam pengaruh jenis matriks terhadap nilai ${ }^{\circ}$ Hue menunjukkan pengaruh yang signifikan dengan nilai $p=0,003$ ( $p<0,05)$. Pengaruh Matriks CMS 1\% dan CMS-alginat $(0,75 \%: 0,25 \%)$ terhadap nilai ${ }^{\circ}$ Hue berbeda nyata dengan matriks CMS-alginat $(0,5 \%: 0,5 \%)$ yang ditunjukkan dengan notasi huruf yang berbeda (Tabel 2).

Berdasarkan hal tersebut maka mikrokapsul dengan matriks CMS-alginat (0,5\%:0,5\%) memiliki warna merah yang paling tajam diantara kedua mikrokapsul dengan kedua jenis matriks lainnya. Carboxymethyl starch (CMS) merupakan pati termodifikasi yang diperoleh dengan mereaksikan pati dengan natrium kloroasetat dalam suasana basa sehingga sifat dari CMS adalah basa. Menurut Bhattacharyya et al. (1995) pH CMS berkisar 8-9. Sifat basa CMS sebagai bahan penyalut ini dapat mempengaruhi warna antosianin. Menurut Xiu-li et al. (2015) stabilitas antosianin di pengaruhi diantaranya oleh pH. Menurut Março et al. (2011) pada $\mathrm{pH}$ 1-2 antosianin stabil berwarna merah karena dominan dalam bentuk kation flavilium, pada $\mathrm{pH}<6$ berubah menjadi karbinol dan sebagian menjadi kuinonoidal yang berwarna biru, pada $\mathrm{pH}$ 6,5-9 dominan berbentuk kuinonoidal yang berwarna biru, dan pada $\mathrm{pH}>9$ antosianin dominan dalam struktur kalkon yang berwarna kuning. Berdasarkan hal tersebut keberadaan CMS yang bersifat basa menyebabkan warna antosianin menjadi cenderung berwarna merah kebiruan. Sehingga mikrokapsul dengan bahan penyalut yang banyak mengandung CMS akan memberikan warna yang cenderung merah kebiruan. Secara lebih jelas visualisasi warna mikrokapsul untuk masing-masing matriks disajikan pada Gambar 4.

Tabel 2. Karaktersitik warna serbuk mikrokapsul antosianin ubi jalar ungu

\begin{tabular}{lccccl}
\hline Jenis Matriks & $\mathbf{L}^{*}$ & $\mathbf{a}^{*}$ & $\mathbf{b}^{*}$ & Hue $\left(^{\mathbf{*}}\right)$ & Chroma $^{*}$ \\
\hline CMS 1\% & $56,31 \pm 0,79^{\mathrm{a}}$ & $12,65 \pm 0,40^{\mathrm{a}}$ & $-7,30 \pm 0,21^{\mathrm{a}}$ & $330,01 \pm 0,08^{\mathrm{a}}$ & $14,60 \pm 0,45^{\mathrm{a}}$ \\
CMS-alginat (0,75\%:0,25\%) & $56,90 \pm 0,25^{\mathrm{a}}$ & $12,40 \pm 0,23^{\mathrm{a}}$ & $-7,18 \pm 0,17^{\mathrm{a}}$ & $329,93 \pm 0,14^{\mathrm{a}}$ & $14,34 \pm 0,28^{\mathrm{a}}$ \\
CMS-alginat (0,5\%:0,5\%) & $57,42 \pm 0,11^{\mathrm{a}}$ & $12,99 \pm 0,19^{\mathrm{a}}$ & $-7,22 \pm 0,12^{\mathrm{a}}$ & $330,95 \pm 0,02^{\mathrm{b}}$ & $14,86 \pm 0,23^{\mathrm{a}}$ \\
\hline
\end{tabular}




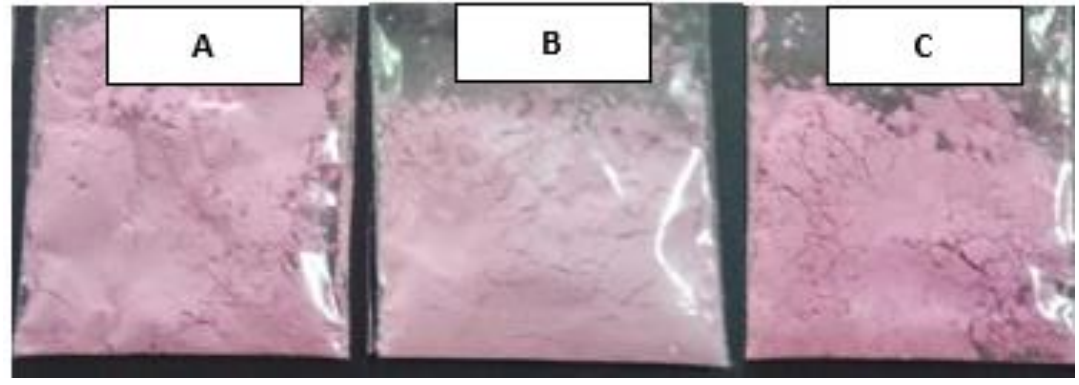

Gambar 4. Mikrokapsul dengan berbagai matriks $\mathrm{A}=\mathrm{CMS} 1 \%, \mathrm{~B}=\mathrm{CMS}$-alginat $(0,75 \%: 0,25 \%), \mathrm{C}=\mathrm{CMS}-$ alginat $(0,5 \%: 0,5 \%)$

Tabel 3. Pengaruh termal terhadap serbuk mikrokapsul antosianin ubi jalar ungu

\begin{tabular}{|c|c|c|c|}
\hline \multirow[b]{2}{*}{ Jenis matriks } & \multicolumn{2}{|c|}{ Konsentrasi (mg/L) } & \multirow{2}{*}{$\begin{array}{c}\text { Penurunan } \\
\text { konsentrasi } \\
(\%)\end{array}$} \\
\hline & $\begin{array}{l}\text { Mikrokapsul antosianin, } \\
\mathrm{T}=\mathbf{3 0}^{\circ} \mathrm{C} \text { (suhu ruang) }\end{array}$ & $\begin{array}{c}\text { Mikrokapsul } \\
\text { antosianin } \mathrm{T}=\mathbf{1 0 0}^{\circ} \mathrm{C}\end{array}$ & \\
\hline CMS $1 \%$ & $221,47 \pm 0,98^{\mathrm{a}}$ & $218,27 \pm 3,41^{\mathrm{a}}$ & $1,44 \pm 1,97^{\mathrm{a}}$ \\
\hline CMS-alginat $(0,75 \%: 0,25 \%)$ & $229,30 \pm 1,21^{\mathrm{b}}$ & $221,10 \pm 1,83^{\mathrm{a}}$ & $3,58 \pm 0,29^{\mathrm{a}}$ \\
\hline CMS-alginat $(0,5 \%: 0,5 \%)$ & $242,42 \pm 1,41^{\mathrm{c}}$ & $210,07 \pm 0,28^{\mathrm{d}}$ & $13,48 \pm 0,39^{\mathrm{b}}$ \\
\hline
\end{tabular}

Keteragan : notasi kolom 1,2 mendatar (signifikansi pengaruh suhu terhadap konsentrasi antosianin pada masingmasing jenis matriks), notasi kolom 3 vertikal (signifikansi pengaruh jenis matriks terhadap penurunan konsentrasi antosianin). $\alpha=0,05$

\section{Stabilitas Termal Mikrokapsul Antosianin Ubi Jalar Ungu}

Selain dipengaruhi oleh $\mathrm{pH}$, stabilitas antosianin dipengaruhi diantaranya juga oleh suhu (Xiu-li et al., 2015). Pada penelitian ini mikrokapsul yang dihasilkan diuji stabilitasnya terhadap pengaruh suhu tinggi selama waktu tertentu. Mikrokapsul yang dihasilkan dipanaskan pada suhu $100^{\circ} \mathrm{C}$ selama 2 jam. Hasil penelitian pengaruh suhu terhadap stabilitas antosianin ditunjukkan pada Tabel 3. Berdasarkan Tabel 3 mikrokapsul dengan matriks CMS $1 \%$ pada suhu ruang memiliki konsentrasi antosianin sebesar $221,47 \pm 0,98 \mathrm{mg} / \mathrm{L}$, mikrokapsul dengan matriks CMS-alginat (0,75\%:0,25\%) memiliki konsentrasi antosianin sebesar 229,30 $\mathrm{mg} / \mathrm{L}$ sebelum dipanasi, dan 242,80 mg/L merupakan konsentrasi antosianin pada mikrokapsul dengan matriks CMS-alginat (0,75\%:0,25\%). Setelah mikrokapsul mendapat pengaruh suhu $100^{\circ} \mathrm{C}$ selama 2 jam pemanasan, konsentrasi antosianin dari mikrokapsul dengan matriks CMS $1 \%$, matriks CMS-alginat $\quad(0,75 \%: 0,25 \%)$, dan matriks CMS:alginat $(0,5 \%: 0,5 \%)$ berturut-turut mengalami penurunan menjadi $218,27 \pm 3,41 \mathrm{mg} / \mathrm{L} ; 221,10 \pm 1,83$

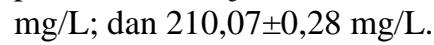

Penurunan tersebut dimungkinkan karena proses pemanasan mendorong terlepasnya bagian glikosil pada antosianin dengan menghidrolisis ikatan glikosidik sehingga terbentuk aglikon tidak stabil dan selanjutnya antosianin kehilangan warna (Yudiono, 2011). Penurunan konsentrasi antosianin yang tinggi menunjukkan kestabilan mikrokapsul yang rendah. Penurunan konsentrasi antosianin pada mikrokapsul ini dapat menjadi indikator kekuatan bahan penyalut dalam meningkatkan kestabilan antosianin.

Dalam penelitian Amr dan Al-Tamimi (2007) menemukan bahwa terjadi penurunan konsentrasi antosianin Ranunculus asiaticus sebesar $42 \%$ dan $48 \%$ setelah 7 jam penyimpanan pada masing-masing suhu $50^{\circ} \mathrm{C}$ dan $80^{\circ} \mathrm{C}$. Turker et al. (2004) melaporkan bahwa terjadi penurunan kadar antosianin wortel hitam, diikuti oleh warna kecoklatan yang meningkat dengan cepat setelah penyimpanan 24 hari pada suhu $40^{\circ} \mathrm{C}$. Menurut penelitian Reyes dan Cisneros-Zevallos (2007), antosianin ubi jalar ungu pada suhu pemanasan $98^{\circ} \mathrm{C}$ mengalami degradasi $50 \%$ pada waktu 2,1 jam $\left(\mathrm{t}_{1 / 2}=\right.$ 2,1 jam) yang mengikuti kinetika orde satu, sedangkan menurut penelitian Mulyawanti et al. (2018) sebanyak 50\% pasta antosianin ubi jalar ungu terdegradasi pada suhu $50^{\circ} \mathrm{C}$ dengan waktu berkisar 32 jam $\left(\mathrm{t}_{1 / 2}=32 \mathrm{jam}\right)$, yang berarti setiap 2 jam terjadi degradasi antosianin sebanyak $\pm 3 \%$. Namun pada penelitian ini, dengan suhu pemanasan $100^{\circ} \mathrm{C}$, antosianin yang sudah tersalut dalam matriks hanya mengalami degradasi konsentrasi dari rentang 1-13\% pada masing-masing jenis matriks. Hal tersebut membuktikan bahwa antosianin yang tersalut dalam matriks berupa bubuk mikrokapsul memiliki kestabilan yang lebih baik dibanding dengan antosianin tanpa terenkapsulat. Matriks yang ditambahkan pada antosianin dapat menjadi dinding yang baik untuk melindungi antosianin dari pengaruh kondisi lingkungan terutama suhu.

Berdasarkan hasil analisa ragam suhu berpengaruh secara signifikan terhadap konsentrasi antosianin dalam mikrokapsul $(p<0,05)$. Signifikansi 
pengaruh suhu pada masing-masing jenis matriks dengan tingkat kepercayaan $95 \% \quad(\alpha=0,05)$ menunjukkan bahwa mikrokapsul dengan matriks CMS $1 \%$ tidak mengalami penurunan secara nyata dan besarnya penurunan hanya berkisar 1,44 \pm $1,97 \%$, sedangkan konsentrasi antosianin yang tersalut dalam matriks CMS-alginat $(0,75 \%: 0,25 \%)$ dan CMS-alginat $(0,5 \%: 0,5 \%)$ mengalami penurunan secara signifikan dengan besarnya penurunan berturut-turut adalah $3,58 \pm 0,29 \%$ dan $13,48 \pm 0,39 \%$.

Penurunan konsentrasi antosianin pada matriks CMS 1\% dan CMS-alginat (0,75\%:0,25\%) tidak berbeda nyata bila dibanding dengan penurunan konsentrasi pada matriks CMS-alginat $(0,5 \%: 0,5 \%)$. Hal ini menunjukkan bahwa matriks CMS-alginat $(0,5 \%: 0,5 \%)$ kurang baik dalam mengenkapsulasi antosianin sedangkan CMS 1\% menjadi matriks terbaik yang dapat mengenkapsulasi antosianin.

Carboxymethyl starch merupakan salah satu karbohidrat yang termodifikasi. Senyawa fenolik seperti antosianin dapat membentuk kompleks dengan karbohidrat (Shahidi dan Naczk, 2004), kompleksasi kation flavilium antosianin dengan karbohidrat mencegah transformasi antosianin ke bentuk lain yang kurang stabil (Chandra et al., 1993). Itulah sebabnya antosianin dengan matriks CMS 1\% memiliki kestabilan yang baik hingga suhu $100^{\circ} \mathrm{C}$.

\section{Karakteristik Morfologi Mikrokapsul Antosianin Ubi Jalar Ungu}

Scanning Electron Microscope (SEM) telah memainkan peran penting dalam meningkatkan pemahaman tentang struktur granular pati termodifikasi (Singh et al., 2007). Dengan demikian untuk memahami struktur granula dari mikrokapsul antosianin dengan bahan penyalut pati termodifikasi (CMS) tersebut dapat dilakukan menggunakan SEM. Menurut Man et al. (1999) diameter partikel dari produk spray dryerberkisar antara 1 hingga $15 \mu \mathrm{m}$.

Menurut Masters (1991), dalam spray drying ukuran partikel dipengaruhi oleh viskositas bahan penyalut, semakin tinggi viskositas semakin besar pula ukuran partikelnya. Selain itu, ukuran partikel menjadi lebih besardapat disebabkan pula oleh proses aglomerasi awal, karena pembentukan jembatan irreversibel menciptakan pembentukan partikel yang lebih besar(Tonon et al., 2008).

Karakteristik morfologi dari ketiga jenis mikropsul disajikan pada Gambar 5. Mikrokapsul dengan matrik CMS $1 \%$ memiliki rata-rata diameter partikel 4,8 $\mu \mathrm{m} \quad$ (Gambar 5A), sementara mikrokapsul dengan matriks CMS-alginat (0,75\%:0,25\%) (Gambar 5B) dan matriks CMSalginat $(0,5 \%: 0,5 \%)$ (Gambar $5 \mathrm{C})$ memiliki rata-rata diameter partikel 4,2 $\mu \mathrm{m}$. Hasil penelitian Kuck dan Noreña (2016), mikrokapsul antosianin dengan teknik spray drying memiliki diameter partikel berkisar 4,8 $\mu \mathrm{m}-14,3 \mu \mathrm{m}$. Dengan demikian ukuran diameter partikel produk mikrokapsul antosianin menggunakan teknik spray drying pada penelitian ini sesuai dengan penelitian Man et al. (1999) serta Kuck dan Noreña (2016). Bentuk mikrokapsul dengan matriks CMS $1 \%$ cenderung berbentuk lingkaran yang halus, meski ada beberapa yang bentuknya tidak teratur (Gambar 5A), hal ini karena terjadi aglomerasi produk bubuk mikrokapsul dengan cepat disebabkan sifat CMS yang higroskopis. Menurut Kuck dan Noreña (2016) agregasi mikrokapsul dengan matriks CMS (pati termodifikasi) ini kemungkinan disebabkan oleh kecenderungan bahan penyalut untuk mengikat air dan membentuk jembatan antar molekul.

Mikrokapsul dengan matriks CMS yang dikombinasikan dengan alginat perbandingan 0,5\% : $0,5 \%$ memiliki bentuk yang bulat yang lebih halus dan tidak terjadi aglomerasi sedangkan pada mikrokapsul dengan matriks CMS-alginat perbandingan $0,75 \%$ : $0,25 \%$ memiliki bentuk dan permukaan yang hampir sama dengan produk mikrokapsul dengan matriks CMS $1 \%$ yaitu berbentuk bulat dengan membentuk agregasi. Penelitian ini sesuai dengan penelitian Villacrez et al. (2014). Hal tersebut menunjukkan bahwa kehadiran CMS menyebabkan terjadinya aglomerasi dengan cepat akibat sifatnya yang mudah mengikat air (mudah larut dalam air dingin).

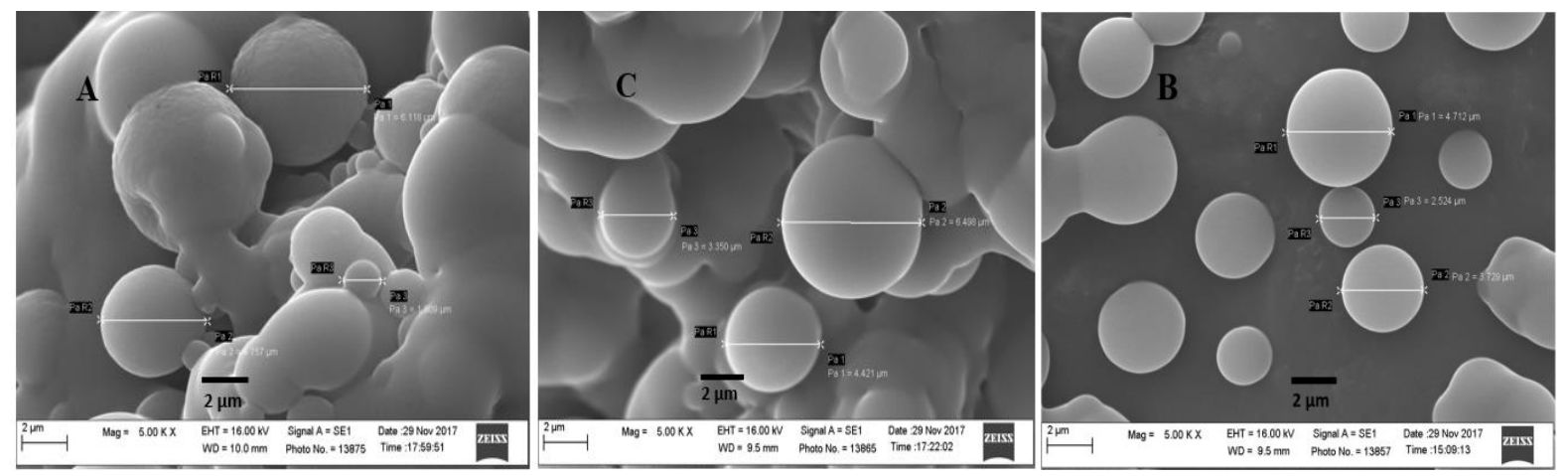

Gambar 5. Morfologi mikrokapsul antosianin ubi jalar ungu dengan SEM perbesaran $5000 \mathrm{x}$ pada berbagai matriks $\mathrm{A}=\mathrm{CMS} 1 \%, \mathrm{~B}=\mathrm{CMS}$-alginat $(0,75 \%$ : $0,25 \%), \mathrm{C}=\mathrm{CMS}$-alginat $(0,5 \%: 0,5 \%)$ 
Carboxymethyl starch (CMS) merupakan pati termodifikasi yang terbentuk melalui proses karboksimetilasi terdiri atas dua tahap yaitu alkalisasi dan eterifikasi. Proses alkalisasi mampu meningkatkan sifat hidrofilik karena mengubah bentuk granula pati dan kristalinitasnya. Peningkatan sifat hidrofilik dapat meningkatkan daya serap CMS terhadap air. akan tetapi, berkurangnya kristalinitas pati menyebabkan struktur pati menjadi lemah dan meluruh setelah granula menyerap sejumlah air (Cardoso et al., 2007), sehingga ketika menyerap air, CMS akan cepat teraglomerasi. Selain itu proses alkalisasi dapat merusak ikatan hidrogen dari $\mathrm{OH}$ pada struktur kristalin dan digantikan oleh gugus karboksimetil. Kehilangan struktur kristalin menyebabkan struktur pati berubah sehingga terjadi peningkatan daerah amorf pati yang menyebabkan carboxymethyl starch mampu mengabsorbsi air (Spychaj et al., 2013), itulah sebabnya CMS memiliki kemampuan mengikat air dengan sangat baik. Dengan demikian untuk menjaga produk tidak mudah teraglomerasi, maka diperlukan agen enkapsulasi lain selain CMS, seperti halnya natrium alginat.

\section{KESIMPULAN DAN SARAN}

\section{Kesimpulan}

Antosianin ubi jalar ungu yang di enkapsulasi menggunakan bahan penyalut CMS $1 \%$ memiliki efisiensi dan rendemen tertinggi dibanding dengan kedua jenis bahan penyalut lainnya masingmasing sebesar $99,37 \pm 0,49 \%$ dan $58,52 \pm 0,23 \%$. Mikrokapsul antosianin ubi jalar ungu dengan matriks CMS 1\% memiliki kestabilan termal terbaik diantara kedua matriks lain. Ukuran partikel rata-rata untuk mikrokapsul antosianin ubi jalar ungu dari berbagai matriks berkisar 4,2-4,8 $\mu \mathrm{m}$ dengan bentuk cenderung bulat berpermukaan halus hingga beragregat.

\section{Saran}

Disarankan untuk pengujian kestabilan
mikrokapsul antosianin ubi jalar selama penyimpanan pada suhu ruang dalam kurun waktu tertentu, sehingga dapat diketahui umur simpan dari mikrokapsul antosianin dalam suhu ruang.

\section{UCAPAN TERIMA KASIH}

Ucapan terima kasih disampaikan kepada Direktorat Jenderal Penguatan Riset dan Pengembangan Kementerian Riset, Teknologi dan Pendidikan Tinggi, dan Pemerintah Indonesia untuk pendanaan dan dukungan terhadap penelitian ini dalam Hibah PMSDU dengan nomer kontrak 1105/IT3.11/LT/2017.

\section{DAFTAR PUSTAKA}

Ahn JH, Kim YP, Seo EM, Choi YK, dan Kim HS. 2007. Antioxidant effect of natural plant extracts on the microencapsulated high oleic sunflower oil. Journal Food Engineering. 84:327-334.

Amr A dan Al-Tamimi E. 2007. Stability of the crude extracts of Ranunculus asiaticus anthocyanins and their use as food colourants. International Journal Food Science Technology. 42 (8) : 985-991.

Arueya GL dan Akomolafe BO. 2014. Stability Studies of Microencapsulated Anthocyanins of Roselle (Hibiscus Sabdariffa L) In Native Starch and Its Potential Application in Jam Production. Journal Environment Science Toxicol Food Technology.8 (7): 112-122.

Bhattacharyya D, Singhal RS, dan Kulkami PR. 1995. Physicochemical properties of carboxymethyl starch prepared from corn and waxy amaranth starch. Carbohydrate Polymers. 27:167-169.

Bryła A, Lewandowicz G, dan Juzwa W. 2015. Encapsulation of elderberry extract into phospholipid nanoparticles. Journal Food Engineering. 167 (Part B):189-195.

Budimarwanti C. 1992. Zat Ivarna berbahaya pada produk'makanan dan minuman. Cakrawala Pendidikan. 11 (2) :103-113.

Burdulis D, Sarkinas A, Jasutiené I, Stackevicené E, Nikolajevas L, Janulis V. 2009. Comparative study of anthocyanin composition, antimicrobial and antioxidant activity in bilberry (Vaccinium myrtillus L.) and blueberry (Vaccinium corymbosum L.) fruits. Acta Pol Pharm. 66:399.

Cardoso MB, Putaux JL, Samios D, da Silveira NP. 2007. Influence of alkali concentration on the deproteinization and/or gelatinization of rice starch. Carbohydrate Polymers. 70: 160-165.

Chandra A, Nair MG, Iezzoni AF. 1993. Isolation and stabilization ofanthocyanins from tart cherries (Prunus cerasus L.). J Agric Food Chem. 41: 1062-1065.

Cavalcanti RN, Santos DT, dan Meireles MAA. 2011. Non-thermal stabilization mechanisms of anthocyanins in model and food systems an overview. Food Res Int. 44(2): 499-509.

Cheng GW dan Breen BJ. 1991. Activity of phenylalanyl ammonialyase (PAL) and concentrations of anthocyanins and phenolics in developping strawberry fruit. $J$ Am Soc Hort Sci.116:865.

Chin SF, Yazid SNAM, dan Pang CM. 2014. Preparation and characterization of starch nanoparticles for controlled release of curcumin. Int J Polym Sci. 2014:1-8.

Chisté RC, LopesAS, dan Faria LJG. 2010. Thermal and light degradation kinetics of anthocyanin 
extracts from mangosteen peel (Garcinia mangostana L.). Int $J$ Food Sci Tech. 45:1902-1908.

Cho J, Kang JS, Long PH, Jing J, Back Y, Chung KS. 2003. Antioxidant and memory enhancing effects of purple sweet potato anthocyanin and cordyceps mushroom extract. Arch Pharmacol Res. 26(10): 821825.

da Rosa CG, Borges CD, Zambiazi RC, Rutz JK, da Luz SR, Krumreich FD, Benvenutti EV, Nunes MR. 2014. Encapsulation of the phenolic compounds of the blackberry (Rubus fruticosus). Food Sci Technol. 30 : 17.

de Oliveira EF, Haroldo C.B. Paula HCB, de Paula RCM. 2014. Alginate/cashew gum nanoparticles for essential oil encapsulation. Colloids Surf B: Biointerfaces. 113:146- 151.

Espevik T, Otterlei M, Skjak-Bræk G, Ryan L, Wright SD, Sundan A. 1993. Theinvolvement of $\mathrm{CD} 14$ in stimulation of cytokine production by uronic acidpolymers. Eur $J$ Immunol. 23:255-261.

Giusti MM dan Wrolstad RE. 2001. Characterization and measurement of anthocyanins by UVVisible spectroscopy.Curr Protoc Food Anal. 1-13.

Gharsallaoui A, Roudaut G, Chambin O, Voilley A, Saurel R. 2007. Applications of spray-drying in microencapsulation of food ingredients: An overview. Food Research International. 40 (9): 1107-1121.

Hu K, Huang X, Gao Y, Huang X, Xiao H, McClements DJ. 2015. Core-shell biopolymer nanoparticle delivery systems: Synthesis and characterization of curcumin fortified zein-pectin nanoparticles. Food Chem.182:275-281.

Hwang YP, Choi JH, Choi JM, Chung YC, Jeong HG. 2011. Protective mechanisms of anthocyanins from purple sweet potato against tert-butyl hydroperoxide-induced hepatotoxicity. Food Chem Toxicol. 49 (9) : 2081-2089.

Jensen MB, Bergamo CA, Payet RM, Liu X, Konczak I. 2011. Influence of copigment derived from Tasmannia pepper leaf on Davidson's plum anthocyanins. J Food Sci. 76:C447-C453.

Kuck LS dan Noreña CPZ. 2016. Microencapsulation of grape (Vitis labrusca var. Bordo) skin phenolic extract using gum Arabic, polydextrose, and partially hydrolyzed guar gum as encapsulating agents. Food Chem. 194:569-576.

Lacerda ECQ, de Araújo Calado VM, Monteiro M, Finotelli PV, Torres AG, Perrone D. 2016. Starch, inulin and maltodextrin as encapsulating agents affect the quality and stability of jussara pulp microparticles. Carbohydr Polym. 151:500-510

Li P, Dou X, Tang Y, Zhu S, Gu J, Feng C, Zhang D. 2012. Gelator-polysaccharidehybrid hydrogel for selective and controllable dye release. J Colloid Interface Sci. 387:115-122.

Mahdavi SA, Jafari SM, Ghorbani M, Assadpoor E. 2014. Spray-Drying microencapsulation of anthocyanins by natural biopolymers: A Review. Dry Technol. 32: 509-518.

Mahmudatussa'adah A, Fardiaz D, Andarwulan N, Kusnandar F. 2014. Karakteristik warna dan aktivitas antioksidan antosianin ubi jalar ungu. J Teknol Indust Pangan. 25(2):176184.

Malien-Aubert C, Dangles O, dan Amiot MJ. 2001. Color stability of commercial anthocyaninbased extracts in relation to the phenolic composition. Protective effects by intra- and intermolecular copigmentation. J Agric Food Chem. 49 (1):170-176.

Man YBC, Irwandi J, Abdullah WJW.1999.Effect of different types of maltodextrin and drying methods on physico-chemical and sensory properties of encapsulated durian flavor. $J$ Sci Food Agric.79:1075-1080.

Masters K. 1991. Spray drying handbook (5th ed.). London: Longman Scientific and Technical.

Março PH, Poppi RJ, Scarminio IS, Tauler R. 2011. Investigation of the $\mathrm{pH}$ effect and UV radiation on kinetic degradation of anthocyanin mixtures extracted from Hibiscus acetosella. Food Chem. 125:10201027. doi:10.1016/j.foodchem.2010.10.005.

Montilla EC, Hillebrand S, Butschbach D, Baldermann S, Watanabe N, Winterhalter. 2010. Preparative isolation of anthocyanins from Japanese purple sweet potato (Ipomoea batatasL.) varieties by high-speed countercurrent chromatography. J Agric Food Chem.58 (18): 9899-9904.

Mulyawanti I, Budijanto S, dan Yasni S. 2010. Stability of Anthocyanin During Processing, Storage and Simulated Digestion of Purple Sweet Potato Pasta.. Int J Agric Sci. 19 (1): $1-8$.

doi: http//dx.doi.org/10.21082/ijas.v.19.n1.2018.p. $1-8$.

Nayak CA dan Rastogi NK. 2010. Effect of selected additives on microencapsulation of anthocyanin by spray drying. Drying Technology. 28: 1396-1404.

Olaya C, Castano M, Garzon G. 2009. Stability of anthocyanin from Rubus glaucus and Solanum betaceum Cav. dark-red strain as affected by temperature, storage and water activity. Acta Biolo gica Colombiana. 14:143-158.

Porrarud S dan Pranee A. 2010. Microencapsulation of Zn-chlorophyll pigment from Pandan leaf 
by spray drying and its characteristic. Food Res Int. 17: 1031-1042.

Reyes LF, Cisneros-Zevallos L. 2007. Degradation kinetics and colour of anthocyanins in aqueous extracts of purple and red-flesh potatoes (Solanum tuberosum L.). Food Chem. 100: 885-894. doi:10.1016/j.foodchem.2005.11.002.

Robert P, Gorena T, Romero N, Sepulveda E, Chavez J, Saenz C. 2010. Encapsulation of polyphenols and anthocyanins from pomegranate (Punica granatum) by spray drying. Int. J Food Sci. Technol.45:13861394.

Robert P,Fredes C. 2015. The encapsulation of anthocyanins from berry-type fruits. Trends in foods. Molecules. 20 (4) : 5875-5888.

Shahidi F, Naczk M. 2004. Phenolics in food and nutraceuticals. New York: CRCPress.

Shaikh JR, Bosale, Singhal R. 2006. Microencapsulation of black pepper oleoresin Journal Food Chem. 94:105-110

Spada JC, Noreña CPZ, Marczak LDF. 2012. Study on the stability of $\beta$-carotene microencapsulated with pinhão (Araucaria angustifolia seeds) starch. Carbohydr Polym. 89 (4):1166-1173

Syafi'i F. 2015. Optimasi proses emulsifikasi dan mikroenkapsulasi pada pembuatan bubuk oleoresin lada (Piper nigrum)[tesis]. Bogor: Institut Pertanian Bogor.

Sangseethong K, Ketsilp S, Sriroth K. 2005. The role of reaction parameters on the preparation and properties of carboxymethyl cassava starch. Starch. 57: 84-93.

Singh J, Kaur L, McCarthy OJ. 2007. Factors influencing the physico-chemical, morphological, thermal and rheological properties of some chemically modified starches for food applications-a review.Food Hydrocoll. 21(1):1-22.

Spychaj T, Zdanowicz M, Kujawa J, Schmidt B. 2013. Carboxymethyl starch with high degree of substitution: synthesis, properties, and application. Polimery. 58:503-511.

Tonon RV, Brabet C, Hubinger MD. 2008. Influence of process conditions on the physicochemical properties of acai (Euterpe oleraceae Mart.) powder produced by spray drying. J Food Eng. 88:411-418.
Torskangerpoll K dan Andersen OM. 2005. Colour stability of anthocyanins in queous solutions at various pH values. Food Chem. 89(3): 427-440.

Turker N, Aksay S, dan Ekiz HI. 2004. Effect of storage temperature on the stability of anthocyanins of a fermented black carrot (Daucus carotavar. L.) beverage: shalgam, $J$ Agric Food Chem.52 (12): 3807-3813.

Varavinit, SN, Chaokkasem, dan Shobsngob S.2001. Studies of flavor encapsulation byagents produced from modified sago andtapioca starches. Starch/Starke. 53: 281-287.

Villacrez JL, Carriazo JG, dan Osorio C. 2014. Microencapsulation of Andes berry (Rubus glaucus benth.) aqueous extract by spray drying. Food Bioprocess Technol.

Winarti C. 2014. Produksi pati garut nanopartikel sebagai matriks enkapsulasi bahan bioaktof herbal [disertasi]. Bogor: Institut Pertanian Bogor

Winarti S, Sarofa U, dan Anggrahini D. 2008.Ekstraksi dan stabilitas warna ubi jalar ungu (Ipomoea batatas L) sebagai pewarna alami. J Tek Kim. 3(1):207-214.

Wu H, Liao C, Jiao Q, Wang Z, Cheng W, Wan Y. 2012. Fabrication of core-shellmicrospheres using alginate and chitosan-polycaprolactone for controlledrelease of vascular endothelial growth factor. React Funct Polym. 72:427437.

Xiu-li HE, Xue-li LI, Yuan-ping LV, Qiang HE. 2015. Composition and color stability of anthocyanin-based extract from purple sweet potato. Food Sci Technol Campinas. 35 (3): 468-473.

Yudiono K. 2011. Ekstraksi antosianin dari ubi jalar ungu (Ipomoea batatas cv. Ayamurasaki) dengan teknik ekstraksi subcritical water. J Tek Pang. 2(1):1-30.

Zaidel DNA, Makhtara NA, Jusoha YMM, Ida Idayu Muhamad II. 2015. Efficiency and Thermal Stability of Encapsulated Anthocyanins from Red Dragon Fruit (Hylocereus polyrhizus (Weber) Britton and Rose) Using Microwave-Assisted Technique. Chem Eng Trans. (43) 